\title{
Chinese Universities: Problems, COVID-19 \& Efforts
}

\section{Universidades Chinas: Problemas, COVID-19 y Esfuerzos}

DOI: $10.46932 / \mathrm{sfjdv} 2 \mathrm{n} 2-188$

Received in: March 1st, 2021

Accepted in: May 30th, 2021

\section{Carlos Rios-Campos}

Investigador RENACYT. Doctor en Gestión Universitaria. Maestro en Administración. Ingeniero de Sistemas. Docente de la Universidad Nacional Toribio Rodríguez de Mendoza de Amazonas. Bagua, Perú.

E-mail: carlos.rios@untrm.edu.pe

\section{Pilar del Rosario Rios Campos}

Maestra en Ciencias con Mención en Informática y Sistemas. Ingeniera de Sistemas. Docente Principal de la Universidad Nacional Pedro Ruiz Gallo. Lambayeque, Perú.

E-mail: prios@unprg.edu.pe

\begin{abstract}
Alberto Lachos Dávila
Maestro en Medicina con Mención en Radioterapia. Médico con Especialidad en Radioterapia. Instituto Nacional de Enfermedades Neoplásicas. Lima, Perú.

E-mail: alachosd1271@yahoo.com
\end{abstract}

\section{Julissa Elizabeth Reyna Gonzalez}

Magister en Educación. Maestra en Administración y Marketing. Candidata a Doctora en Educación. Docente de la Universidad Nacional Hermilio Valdizan. Huánuco, Perú. Docente de la Escuela de Posgrado Universidad Cesar Vallejo. Lima, Perú.

E-mail: jreynag555@gmail.com

\section{Victor Ricardo Flores Rivas}

Doctor en Gestión Pública y Gobernabilidad. Magister en Docencia Universitaria. Docente de la

Universidad Continental. Lima, Perú.

E-mail: vflores@continental.edu.pe

\section{Freddy Manuel Camacho Delgado}

Doctor en Economía. Economista. Docente Principal de la Universidad Nacional Intercultural Fabiola

Salazar Leguía de Bagua. Bagua, Perú.

E-mail: fcamacho@unibagua.edu.pe

Juan Manuel Raunelli Sander

Maestro en Educación con Mención en Psicología Educativa. Economista. Docente de la Universidad

Señor de Sipán. Pimentel, Perú.

E-mail: jmvrs56@gmail.com

\section{Irma Rumela Aguirre Zaquinaula}

Doctora en Administración de la Educación. Docente Ordinaria Asociada de la Universidad Nacional de Jaén. Jaén, Perú.

E-mail: irma.aguirre@unj.edu.pe 


\begin{abstract}
It is necessary to know the state of the Chinese universities. In this paper the general objective was determine the situation of Chinese universities: Problems, COVID-19 \& efforts. Methodology, in this research, 31 documents have been selected, carried out in the period 2016 - 2021; including: scientific articles, review articles and information from websites of recognized organizations. The keywords used in the searches were: Chinese universities and COVID-19. Results, China has approximately 2,845 universities, which are gradually improving their infrastructure and academic level. The percentage of women has increased (UIS.UNESCO, 2021). A close collaboration between the university and the industry was presented as they refer (Hou, Hong \& Shi, 2021). Employers consider the University of Hong Kong to have the best graduates (SICAS, 2018). Difficulty deciding what to investigate. The situation in Chinese universities is stabilizing, after COVID-19 was presented, continuing with virtual courses and the intensive use of ICTs. In addition, the progressive opening of these institutions, monitoring the health of students and teachers. Conclusions, Chinese universities are ranking better in world rankings such as the QS World University Rankings. They are overcoming the limitations imposed by COVID-19. The number of graduates, researchers and patents is considerable and competes with the great powers of Europe, Asia and North America. In addition, some of its universities are achieving international recognition and have students from various parts of the world.
\end{abstract}

Keywords: Chinese universities, COVID-19.

\title{
RESUMEN
}

Es necesario conocer el estado de las universidades chinas. En este trabajo el objetivo general fue determinar la situación de las universidades chinas: problemas, COVID-19 y esfuerzos. Metodología, en esta investigación se han seleccionado 31 documentos, realizados en el período 2016 - 2021; incluyendo: artículos científicos, artículos de revisión e información de sitios web de organizaciones reconocidas. Las palabras clave utilizadas en las búsquedas fueron: universidades chinas y COVID-19. Resultados, China tiene aproximadamente 2.845 universidades, las cuales están mejorando gradualmente su infraestructura y nivel académico. El porcentaje de mujeres ha aumentado (UIS.UNESCO, 2021). Se presentó una estrecha colaboración entre la universidad y la industria como se refieren (Hou, Hong \& Shi, 2021). Los empleadores consideran que la Universidad de Hong Kong tiene los mejores graduados (SICAS, 2018). Dificultad para decidir qué investigar. La situación en las universidades chinas se está estabilizando, luego de la presentación del COVID-19, continuando con los cursos virtuales y el uso intensivo de las TIC. Además, la progresiva apertura de estas instituciones, monitoreando la salud de estudiantes y docentes. Conclusiones, las universidades chinas están mejor posicionadas en rankings mundiales como el QS World University Rankings. Están superando las limitaciones impuestas por COVID-19. El número de titulados, investigadores y patentes es considerable y compite con las grandes potencias de Europa, Asia y Norteamérica. Además, algunas de sus universidades están logrando reconocimiento internacional y cuentan con estudiantes de diversas partes del mundo.

Palabras clave: Universidades chinas, COVID-19.

\section{INTRODUCTION}

China is located at the east coast of the largest continent (Eurasia) as well as the western margin of the largest ocean (Pacific). It has a land area of about 9.6 million square km, occupying 6.5 percent of the total land area of the world...Its population of more than 1.3 billion accounts for approximately onefifth of the world population (Campuschina, 2016). 
84 different universities in China are featured in the QS World University Rankings by Subject 2020 and this year's subject rankings cover 48 different subjects. With so much choice, it can be difficult to decide which university is right for you (Lane, 2021)

While the rapid expansion of non-English foreign language degree programs potentially enables Chinese universities to play a critical role in promoting the learning and teaching of non-English foreign languages in China, it has become imperative for these universities to engage in carefully coordinated efforts so that this growth can be sustained (Yawen, Xuesong \& Jinyuan, 2019).

Findings reveal that the fundamental goal of academic personnel system reforms for leading Chinese research universities was to address increasing global competition and stimulate research outputs within a new managerial context (Wang \& Jones, 2021).

We analyse data from 176 Chinese universities to examine the use of reputation symbols on official websites. We find that Chinese universities prefer professional and performative symbols more than moral symbols (Christensen \& Ma, 2020).

Using panel data from 522 universities in China (2005 to 2015), this paper examines the effect of a university's name change on student admission scores... The results indicate that, in general, a name change did not significantly improve the admission score of the university (Shi, Liu \& Kang, 2020).

This paper reports on a study that examines the plagiarism policies made publicly available by eight major universities of foreign studies in mainland China. Both the structure and content of these universities' policy documents are analyzed to identify institutional understandings of, attitudes toward, and sanctions on plagiarism (Guangwei \& Xiaoya, 2017).

We collected student data from five public sector universities in Anhui Province, China, ...we analyzed the collected quantitative data through multiple regression analysis. Our research results demonstrate that external and internal factors have a great influence on plagiarism (Fatima, Abbas, Ming, Hosseini \& Zhu, 2019).

It is important to know the problem during the pandemic and the efforts of Chinese universities, in the current context.

\section{METHODOLOGY}

The research presents a qualitative-interpretative design, of a documentary type, which specified the selection procedure and the data recording (Barrero y Rosero, 2018).

In this research, 31 documents have been selected, carried out in the period 2016 - 2021; including: scientific articles, review articles and information from websites of recognized organizations. The keywords used in the searches were: Chinese universities and COVID-19. For the selection of the 
Table 1. Bibliographic matrix

\begin{tabular}{|l|l|l|l|}
\hline Name & Type & Objectives & Conclusions \\
\hline & & & \\
\hline
\end{tabular}

Source: Adapted from Barrero \& Rosero (2018).

\section{RESULTS}

The total number of universities in China is approximately 2845, with 13 types of buildings. The annual energy consumption is nearly 30 million tons of standard coal, and the water consumption is nearly 4 million tons. The total energy consumption accounts for $8 \%$ of the total social energy consumption (Liu \& Ren, 2020).

Figure 1. Tertiary education by sex

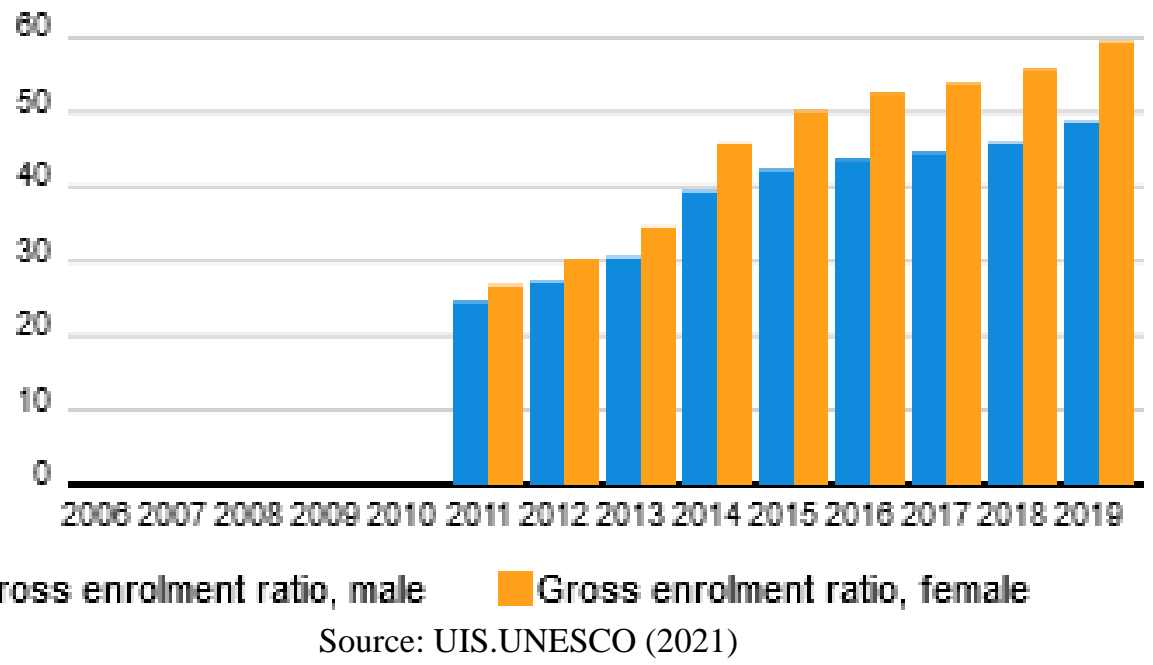

We found that the university-industry collaboration efficiency is determined by a university's characteristics, scientific research fund from the government, and regional economic status. We also found heterogeneous effects across samples (Hou, Hong \& Shi, 2021).

Finally, universities had for several years been improving their own technical preparedness for online learning. An example is Zhejiang University, which since 2018 had built a wide spectrum of smart classrooms, equipped with audio recognition and simultaneous interpretation (Varghese, 2021). 
Figure 2. Chinese Universities

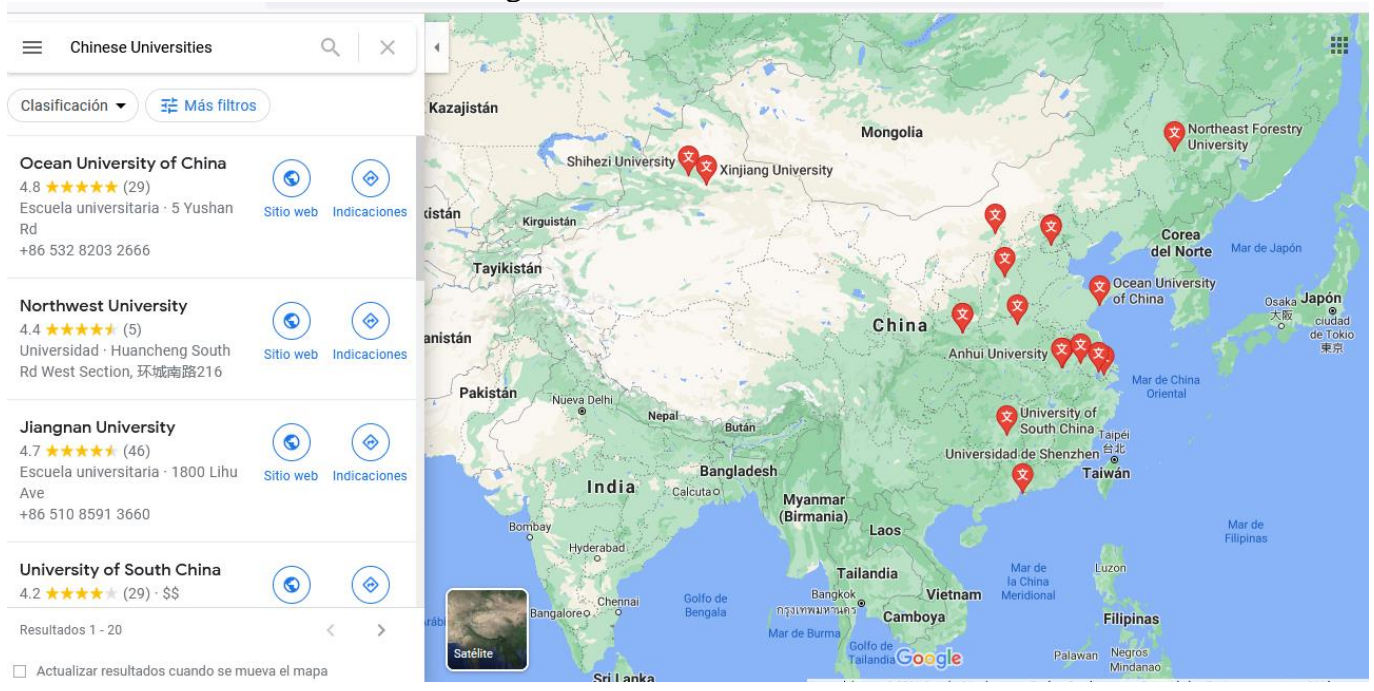

Source: Google maps (2021)

Figure 3. Postgraduate students attend the commencement ceremony at Tsinghua University in Beijing, capital of China, July $2,2016$.

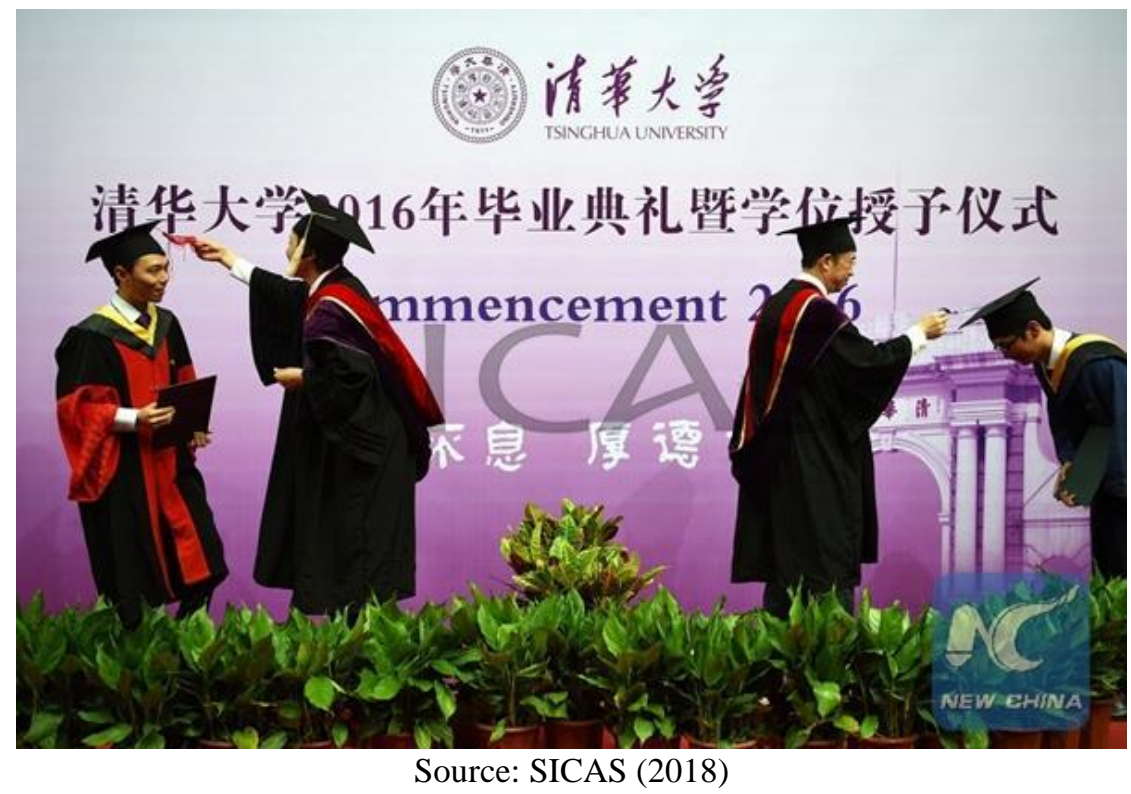

The ranking shows that employers consider Hong Kong University of Science and Technology (HKUST) to be the best Chinese institution at producing graduates with the skills they need for the workplace. HKUST was ranked 13th in this global ranking of 150 universities. The next five Chinese institutions...Peking University (17th), Fudan University (37th), Shanghai Jiao Tong University (53rd), Tsinghua University (59th) and National Taiwan University of Science and Technology (73rd) (SICAS (2018). 


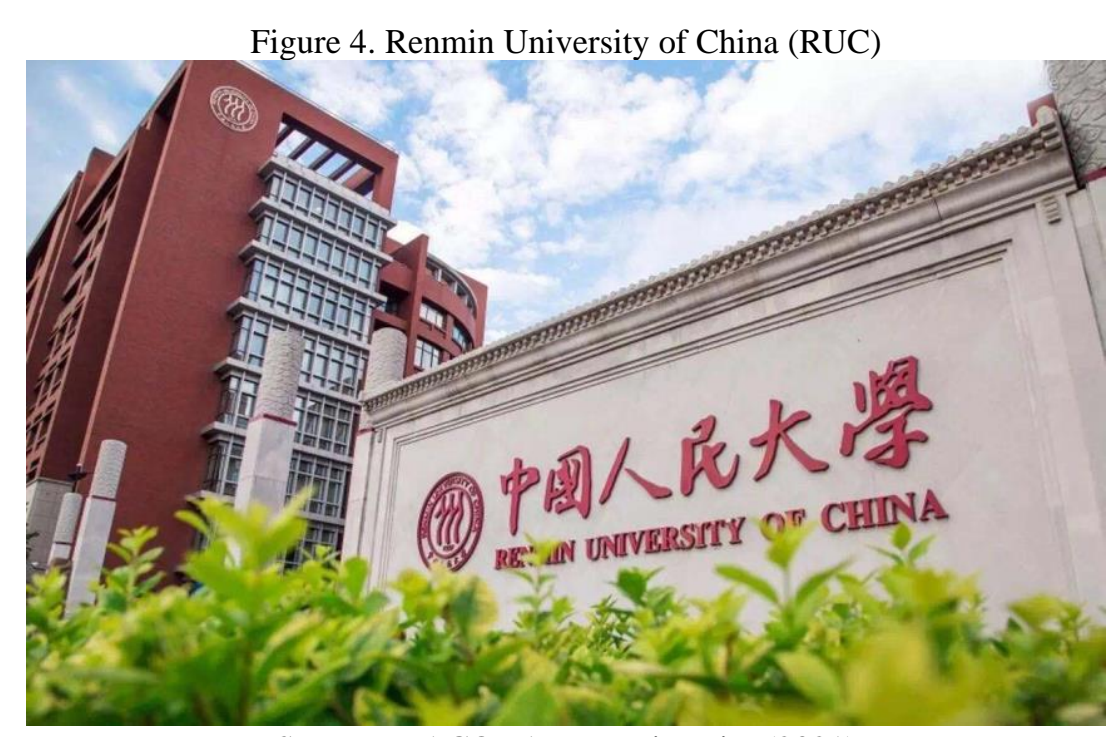

Source: MACQUARIE University (2021)

Renmin University of China (RUC) is the first comprehensive research university established by the People's Republic of China. Its predecessor was Shanbei Public School, founded in 1937 (MACQUARIE University, 2021).

\section{PROBLEMS}

Three major dilemmas that may be created for Chinese HSS academics by their country's aspirations for world-class universities...first, a highly centralised system restrains academics' autonomy to decide what to research and where to publish. Second, they are conflicted by the need to simultaneously attend to nationalistic interests and publish internationally. Third, ideological correctness is highly important (Gao \& Zheng, 2020).

The study revealed that Chinese academics are concerned about international students' learning attitudes, their academic progress and a lack of participation due to their language ability. Local Chinese students also reported a lack of satisfaction in working with international students (Han, Li, Bao \& Cao, 2020).

About the inefficiency and productivity of 64 Chinese research universities and their evolution over the recent period of 2010-2013,... the efficiency increased on average over the period of 2010-2013. However, technical changes for many universities were below zero, which led to technology deterioration on average (Yang, Fukuyama \& Song, 2018).

\section{COVID-19}

Since the onset of the new coronavirus, Covid-19 in December last year, nearly every aspect of daily life in China has changed. .. suddenly, several hundred million students started taking classes via 
web platforms. On 17 February, the internet crashed in China due to the sudden increase of users who were simultaneously logging in (Yu, 2020).

In view of the current pandemic by SARS-CoV-2 it deems essential to understand the key concepts about the infection: its epidemiological origin, presentation, clinical course, diagnosis and treatment (still experimental in many cases) (Rubio-Pérez, Badía, Mora-Rillo, Martin, García Rodríguez \& Balibrea, 2020).

On September 18, the Ministry of Education told universities to "dynamically adjust campus control measures." For students who really need to enter and exit schools due to internships, job searches and other reasons, the procedures shall be simplified, said the notice. The ministry said that schools should "avoid a one-size-fits-all approach" in campus management (Shasha \& Xi, 2020).

In these moving testimonials from international research students and staff in China, during the Covid-19 pandemic outbreak, we hear warm, individual tales of personal struggles, at the point when life and work changed beyond all recognition (Peters, Wang, Ogunniran, et al., 2020).

It was concluded that Chinese undergraduate students during COVID-19 outbreak showed higher anxiety. However, in general the psychological status of university students was fairly good, which laid a good foundation for the new term's online-learning (Wang \& Zhao, 2020).

The deadly coronavirus outbreak presents a host of challenges for different sectors of society. University campuses with their congregate settings are considered particularly susceptible to contagion. As China continues to battle the epidemic, universities across the country have followed public health guidance to shut campuses.

As the backbone of Chinese society, Chinese universities have made significant contributions to emergency risk management. Such contributions have been made primarily in the following areas: alumni resource collection, medical rescue and emergency management, mental health maintenance, control of staff mobility, and innovation in online education models (Wang, Cheng, Yue \& McAleer, 2020).

The COVID-19 situation appears to be stabilizing in China and schools are gradually opening up to students after an extended winter/spring break. The next challenge for Chinese schools and institutions is to ensure campus safety and monitor the health of all students, faculty and staff as they return to faceto-face learning (Australian Government, 2020).

\section{EFFORTS}

In contrast, the contribution of universities in the USA/EU/Japan is significantly beneficial to foreign-invested firms. Collaboration with domestic universities has played a significant role in the diffusion of advanced technology in China (Fu \& Li, 2016). 
The evidence showed that there is a feedback channel between university patent commercialization and knowledge innovation, and new knowledge generated by the interaction with the outside world in the process of patent commercialization was transmitted to the subject of knowledge innovation through this channel, forming a virtuous dynamic cycle (Gong, Nie, Peng, Peng \& Liu, 2020).

Figure 5. Best Global Universities in China

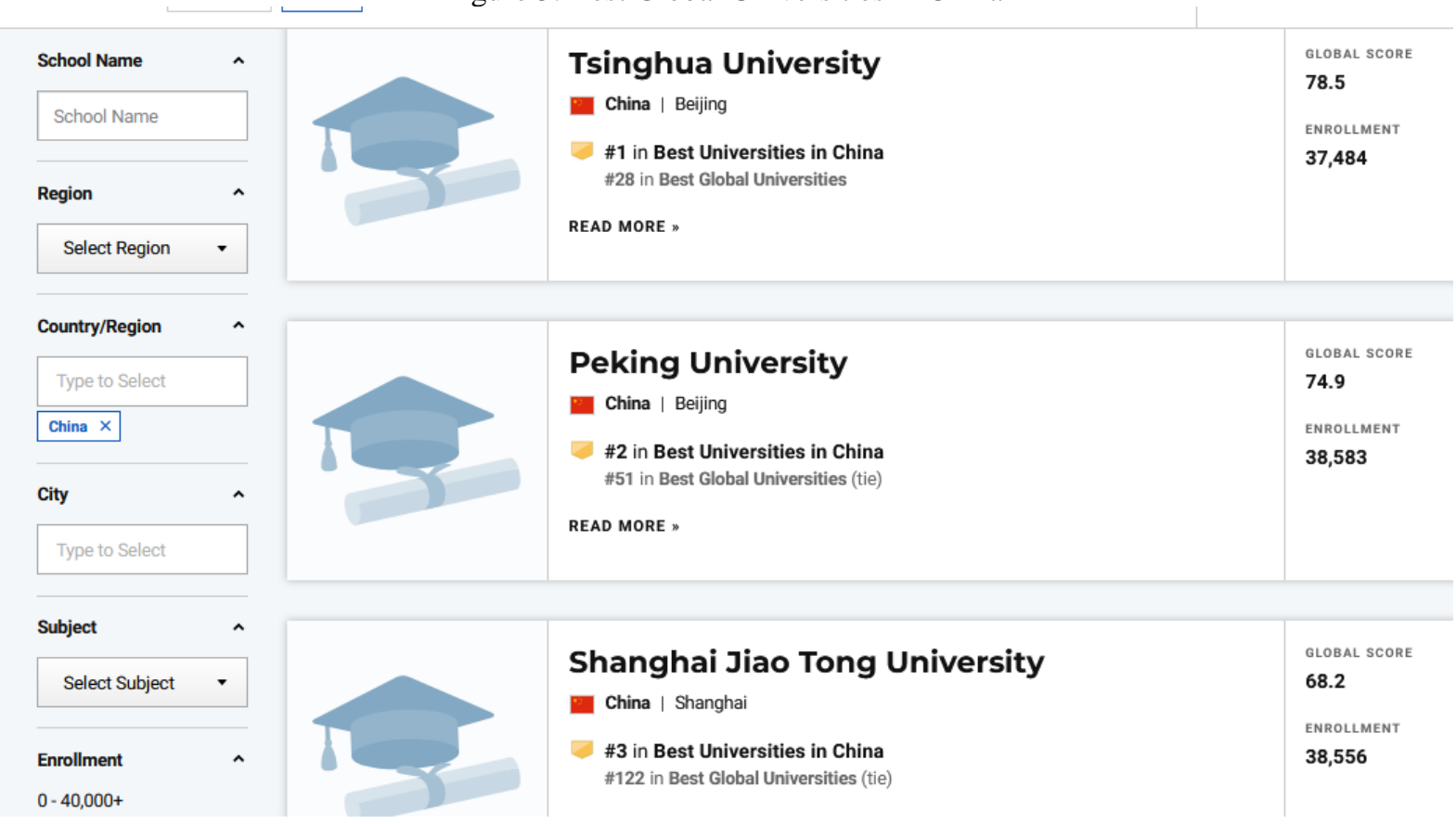

Source: U.S. News (2021)

In this context, the Chinese Ministry of Education (MoE) and several education specialists and universities have started discussing the use of information and communication technology (ICT) to reform the entire educational system in the midst of this pandemic and provide online and distance learning instead, even with disrupted classes (Huang, Tlili, Chang et al., 2020).

With all the campuses closed, universities swung into action to open 24,000 online courses, including 1,291 of China's 'national excellence courses' (competitive high-quality courses selected by the Ministry of Education) and 401 courses of virtual experimental simulations, provided on 22 platforms (Sun, Tang \& Zuo, 2020).

China has approximately 2,845 universities, which are gradually improving their infrastructure and academic level. The percentage of women has increased (UIS.UNESCO, 2021). A close collaboration between the university and the industry was presented as they refer (Hou, Hong \& Shi, 2021). Employers consider the University of Hong Kong to have the best graduates (SICAS, 2018). Difficulty deciding what to investigate. The situation in Chinese universities is stabilizing, after COVID-19 was presented, 
continuing with virtual courses and the intensive use of ICTs. In addition, the progressive opening of these institutions, monitoring the health of students and teachers.

\section{CONCLUSIONS}

Chinese universities are ranking better in world rankings such as the QS World University Rankings. They are overcoming the limitations imposed by COVID-19. The number of graduates, researchers and patents is considerable and competes with the great powers of Europe, Asia and North America. In addition, some of its universities are achieving international recognition and have students from various parts of the world. 


\section{BIBLIOGRAPHIC REFERENCES}

Australian Government (2020). China's education arrangements during COVID-19 pandemic period. Retrieved from https://internationaleducation.gov.au/international-network/china/PolicyUpdatesChina/Pages/China\%27s-education-arrangements-during-COVID-19-pandemic-period.aspx

Barrero, A. \& Rosero, A. (2018). Estado del Arte sobre Concepciones de la Diversidad en el Contexto Escolar Infantil. Revista Latinoamericana de Educación Inclusiva, 2018, 12(1), 39-55 https://doi.org/10.4067/S0718-73782018000100004

$\begin{array}{lllll}\text { Campuschina } & \text { (2016). } & \text { China } & \text { Overview. }\end{array}$ https://www.campuschina.org/about_china/index.html

Christensen, T. \& Ma, L. (2020). Chinese University Administrations: Chinese Characteristics or Global Influence?, Higher Education Policy, 10.1057/s41307-020-00208-8

Fatima, A., Abbas, A., Ming, W., Hosseini, S. \& Zhu, D. (2019). Internal and External Factors of Plagiarism: Evidence from Chinese Public Sector Universities, Accountability in Research, 26:1, 1-16, DOI: $10.1080 / 08989621.2018 .1552834$

Fu, X. \& Li, J. (2016). Collaboration with foreign universities for innovation: evidence from Chinese manufacturing firms. https://doi.org/10.1504/IJTM.2016.075162

Gao, X. \& Zheng, Y. (2020). 'Heavy mountains' for Chinese humanities and social science academics in the quest for world-class universities, Compare: A Journal of Comparative and International Education, 50:4, 554-572, DOI: 10.1080/03057925.2018.1538770

Gong, H., Nie, L., Peng, Y., Peng, S. \& Liu, Y. (2020). The innovation value chain of patents: Breakthrough in the patent commercialization trap in Chinese universities. PLoS ONE 15(3): e0230805. https://doi.org/10.1371/journal.pone.0230805

Guangwei $\mathrm{Hu} \&$ Xiaoya Sun (2017). Institutional policies on plagiarism: The case of eight Chinese universities of foreign languages/international studies. System. Volume 66, Pages 56-68. https://doi.org/10.1016/j.system.2017.03.015.

Han Y, Li W, Bao M, Cao X. (2020). An Investigation of the Experiences of Working with Multilingual International Students among Local Students and Faculty Members in Chinese Universities. Sustainability. 12(16):6419. https://doi.org/10.3390/su12166419

Hou, B., Hong, J. \& Shi, X. (2021). Efficiency of university-industry collaboration and its determinants: evidence from Chinese leading universities, Industry and Innovation, 28:4, 456-485, DOI: $10.1080 / 13662716.2019 .1706455$

Huang, R., Tlili, A., Chang, TW. et al. (2020). Disrupted classes, undisrupted learning during COVID-19 outbreak in China: application of open educational practices and resources. Smart Learn. Environ. 7, 19. https://doi.org/10.1186/s40561-020-00125-8

Lane, C. (2021). Top Universities in China by Subject. Retrieved from https://www.topuniversities.com/university-rankings-articles/university-subject-rankings/topuniversities-china-subject 
Liu, Q. \& Ren, J. (2020). Research on the building energy efficiency design strategy of Chinese universities based on green performance analysis. Energy and Buildings, Volume 224, 2020, 110242. https://doi.org/10.1016/j.enbuild.2020.110242.

MACQUARIE University (2021). Semester Exchange - Renmin University of China. Retrieved from https://www.mq.edu.au/study/international-students/staging/details/semester-exchange-renminuniversity-of-china

Peters, M.A., Wang, H., Ogunniran, M.O. et al. (2020). China's Internationalized Higher Education During Covid-19: Collective Student Autoethnography. Postdigit Sci Educ 2, 968-988. https://doi.org/10.1007/s42438-020-00128-1

Rubio-Pérez I, Badía JM, Mora-Rillo M, Martin Quirós A, García Rodríguez J \& Balibrea JM. (2020). COVID-19: conceptos clave para el cirujano. Cir Esp. 98: 310-319.

SICAS (2018). 14 Chinese universities make into THE global university employability ranking. Retrieved from https://www.sicas.cn/Students/Info/Content_180815152840596.shtml

Shasha, C. \& Xi, Y. (2020). Chinese universities adopt flexible COVID-19 curbs ahead of National Day. Retrieved from https://www.globaltimes.cn/content/1201605.shtml

Shi, Y., Liu, R. \& Kang, Y. (2020). Does a name change attract better students? Evidence from Chinese universities. China Economic Review, Volume 101395. https://doi.org/10.1016/j.chieco.2019.101395.

Sun, L., Tang, Y. \& Zuo, W. (2020). Coronavirus pushes education online. Nat. Mater. 19, 687. https://doi.org/10.1038/s41563-020-0678-8

UIS.UNESCO (2021). Participation in Education. Retrieved from http://uis.unesco.org/en/country/cn U.S. News (2021). Best Global Universities in China. Retrieved from https://www.usnews.com/education/best-global-universities/china

Varghese, T. (2021). Covid-19 has reinforced China's role as global leader in edtech. Retrieved from https://www.timeshighereducation.com/campus/covid19-has-reinforced-chinas-role-global-leaderedtech

Wang, S. \& Jones, G. (2021). Competing institutional logics of academic personnel system reforms in leading Chinese Universities, Journal of Higher Education Policy and Management, 43:1, 49-66, DOI: 10.1080/1360080X.2020.1747958

Wang, C., \& Zhao, H. (2020). The Impact of COVID-19 on Anxiety in Chinese University Students. Frontiers in psychology, 11, 1168. https://doi.org/10.3389/fpsyg.2020.01168

Wang, C., Cheng, Z., Yue, X. \& McAleer, M. (2020). Risk Management of COVID-19 by Universities in China. Journal of Risk and Financial Management, MDPI, Open Access Journal, vol. 13(2), pages 1-6, February. 
Weforum (2020). How a top Chinese university is responding to coronavirus. Retrieved from https://www.weforum.org/agenda/2020/03/coronavirus-china-the-challenges-of-online-learning-foruniversities/

Yang, G., Fukuyama, H. \& Song, Y. (2018). Measuring the inefficiency of Chinese research universities based on a two-stage network DEA model, Journal of Informetrics. Volume 12, Issue 1, Pages 10-30. https://doi.org/10.1016/j.joi.2017.11.002.

Yawen Han, Xuesong Gao \& Jinyuan Xia (2019) Problematising recent developments in non-English foreign language education in Chinese universities, Journal of Multilingual and Multicultural Development, 40:7, 562-575, DOI: 10.1080/01434632.2019.1571072

$\mathrm{Yu}$, J. (2020). Covid-19 and the challenges of remote teaching in China. Retrieved from https://blog.cambridgeinternational.org/covid-19-and-the-challenges-of-remote-teaching-in-china/ 